\title{
Impact of the Legume Catch Crop Serradella on Subsequent Growth and P Mobilization under Barley in Different Fertilization Treatments
}

\author{
Nora Vitow ${ }^{1}\left(\mathbb{D}\right.$, Theresa Zicker ${ }^{2}$, Akane Chiba ${ }^{3,4}$, Anika Zacher $\left.{ }^{1}{ }^{(}\right)$, Bettina Eichler-Löbermann ${ }^{2}{ }^{(0)}$, \\ Stefanie Schulz ${ }^{3}\left[{ }^{10}\right.$, Michael Schloter $^{3}$, Christel Baum $^{1, *}$ and Peter Leinweber ${ }^{1}$ \\ 1 Soil Science, Faculty of Agricultural and Environmental Sciences, University of Rostock, \\ Justus-von-Liebig-Weg 6, D-18059 Rostock, Germany; nora.vitow@uni-rostock.de (N.V.); \\ anika.zacher@uni-rostock.de (A.Z.); peter.leinweber@uni-rostock.de (P.L.) \\ 2 Agronomy and Crop Science, Faculty of Agricultural and Environmental Sciences, University of Rostock, \\ Justus-von-Liebig-Weg 6, D-18059 Rostock, Germany; theresa.zicker2@uni-rostock.de (T.Z.); \\ bettina.eichler@uni-rostock.de (B.E.-L.) \\ 3 Research Unit Comparative Microbiome Analysis, Helmholtz Zentrum München, \\ Deutsches Forschungszentrum für Gesundheit und Umwelt (GmbH), Ingolstädter Landstr. 1, \\ D-85764 Neuherberg, Germany; akane.101@hotmail.com (A.C.); \\ stefanie.schulz@helmholtz-muenchen.de (S.S.); schloter@tum.de (M.S.) \\ check for \\ updates \\ Citation: Vitow, N.; Zicker, T.; Chiba, \\ 4 Crop Physiology, TUM School of Life Science, Technical University of Munich, Alte Akademie 12, \\ D-85354 Freising, Germany \\ * Correspondence: christel.baum@uni-rostock.de; Tel.: +49-381-4983100
} A.; Zacher, A.; Eichler-Löbermann, B. Schulz, S.; Schloter, M.; Baum, C.; Leinweber, P. Impact of the Legume Catch Crop Serradella on Subsequent Growth and P Mobilization under Barley in Different Fertilization Treatments. Agronomy 2021, 11, 2437. https://doi.org/10.3390/ agronomy11122437

Academic Editors: Othmane Merah, Purushothaman Chirakkuzhyil Abhilash, Magdi T. Abdelhamid, Hailin Zhang and Bachar Zebib

Received: 15 November 2021 Accepted: 27 November 2021 Published: 29 November 2021

Publisher's Note: MDPI stays neutral with regard to jurisdictional claims in published maps and institutional affiliations.

Copyright: (c) 2021 by the authors. Licensee MDPI, Basel, Switzerland. This article is an open access article distributed under the terms and conditions of the Creative Commons Attribution (CC BY) license (https:// creativecommons.org/licenses/by/ $4.0 /)$.

Abstract: Legume catch crops can enhance soil fertility and promote the $\mathrm{N}$ and $\mathrm{P}$ supply of the subsequent main crop, especially with low mineral fertilizer use. However, the specific impact of catch crops on arbuscular mycorrhiza formation of the following main crop is unknown. Therefore, the impact of serradella (Ornithopus sativus) vs. bare fallow was tested on mycorrhiza formation, potential soil enzyme activities and plant-available $\mathrm{P}$ under subsequently grown barley (Hordeum vulgare) and different fertilization treatments (P-unfertilized-P0; triple superphosphate-TSP; compost$\mathrm{COM}$; combined-COM + TSP) in a long-term field experiment in northeastern Germany. Catch cropping significantly increased mycorrhiza formation of barley up to $14 \%$ compared to bare fallow. The impact of serradella on mycorrhiza formation exceeded that of the fertilization treatment. Serradella led to increased phosphodiesterase activities and decreased B-glucosidase activities in soil. Plant availability of $\mathrm{P}$ was not significantly affected by serradella. These findings provide initial evidence that even serradella as a non-host crop of mycorrhizal fungi can promote the mycorrhiza formation of the subsequent crop and P mobilization in soil. We conclude that the prolonged vegetation cover of arable soils by the use of catch crops can promote $\mathrm{P}$ mobilization and transfer from $\mathrm{P}$ pools to the following main crops.

Keywords: mycorrhiza; P fertilization; catch crop; barley; crop rotation; P mobilization

\section{Introduction}

Phosphorus $(\mathrm{P})$ is an essential plant nutrient which is often the determining factor for proper yields in agriculture. Despite the partly large total $\mathrm{P}$ pools in soil, only a small portion of it is plant-available, and low plant availability of $\mathrm{P}$ in soil can limit plant performance and growth [1]. Consequently, high and sustainable crop production requires P supplements. However, supplementary mineral $\mathrm{P}$ fertilizers are produced from mining deposits, which are finite and often contaminated with cadmium and uranium [2-4]. Thus, $P$ fertilizer applications need to be reduced by an increased efficiency of the $P$ use from the soil P pool.

Plants and microorganisms jointly contribute to P mobilization from the less mobile $\mathrm{P}$ pools in soil. Arbuscular mycorrhizal (AM) fungi link microbial P mobilization with 
$\mathrm{P}$ transfer to plants and can significantly enhance the plant $\mathrm{P}$ use efficiency of their host plants from the soil $\mathrm{P}$ pools by increasing the soil volume out of which $\mathrm{P}$ is acquired by their mycelial network [5-7]. In addition, AM fungi can promote plant growth by the mitigation of abiotic and biotic stress [8-11]. Plant symbionts depend on the presence of host plants. Therefore, crop rotation and periods of bare soil have a significant impact on AM fungi and on P cycling in soil [12,13]. Catch crop cultivation can contribute to increasing the $\mathrm{P}$ availability for the subsequent crop and minimize the risk of nutrient losses from soil $[14,15]$. The variety of plant species used as catch crops is constantly expanding, but legumes are particularly relevant due to their combined abilities for $\mathrm{N}_{2}$ fixation and efficient $P$ mobilization [16-18]. A frequently used legume catch crop in warm and humid climate zones is serradella (Ornithopus sativus) [19]. This legume forms nodules with symbiotic diazotrophic bacteria of the genus Bradyrhizobium, which have the ability to promote the host plant's growth by an improved N supply and P mobilization [20,21]. In contrast to the majority of legumes, serradella is non-host plant of AM fungi but acquires $\mathrm{P}$ mostly by the use of its long $(>0.40 \mathrm{~mm})$ root hairs [22]. Other non-host plants of mycorrhizal fungi, such as Indian mustard (Brassica juncea), were revealed to decrease the subsequent mycorrhizal colonization of host crops in the crop rotation [23,24]. Serradella has not yet been tested for its potential impact on the subsequent mycorrhiza formation of host crops, although it seems to be a very promising crop to promote P use efficiency from the soil pool in general.

Therefore, we investigated the crop-specific impact of serradella on a subsequent mycorrhizal main crop (Hordeum vulgare) under different $P$ fertilization treatments. We hypothesized the following: (I) the addition of nitrogen by symbiotic diazotrophic and P-mobilizing bacteria will promote the subsequent $\mathrm{P}$ supply and growth of barley; (II) alternatively, serradella, as a non-mycorrhizal crop, can decrease the mycorrhiza formation and P supply of subsequent grown barley by decreased $\mathrm{P}$ transfer to the host plants.

\section{Materials and Methods}

\subsection{Experimental Design and Sampling}

The study was conducted in 2018 and 2019 at a long-term field experiment (LTFE) with a constant fertilizer regime since 1998 in northern Germany ( $\left.54^{\circ} 3^{\prime} 41.47^{\prime \prime} \mathrm{N} ; 12^{\circ} 5^{\prime} 5.59^{\prime \prime} \mathrm{E}\right)$. The predominant soil unit is a Stagnic Cambisol according to the World Reference Base for Soil Resources [25]. The soil texture of the topsoil has been characterized as loamy sand. The mean temperature during the vegetation period was $11.5^{\circ} \mathrm{C}$ and the mean precipitation was $460 \mathrm{~mm}$ (Figure 1).

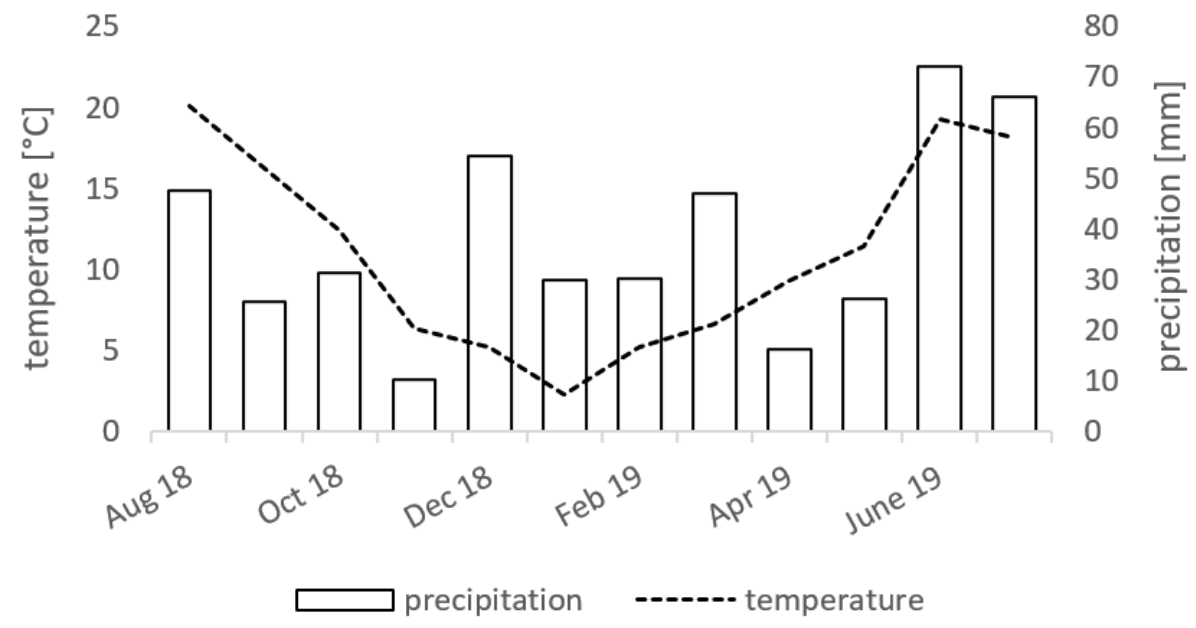

Figure 1. Temperature (line, monthly mean) and precipitation (bars, monthly sum) at the experimental test site in Rostock within the vegetation period from August 2018 to July 2019. 
The LTFE included nine fertilizer treatments and was arranged as a randomized splitplot in four replicates with a plot size of $5 \times 6 \mathrm{~m}$. This study focused on plots with four fertilizer treatments: triple superphosphate (TSP), biowaste compost (COM), a combination of biowaste compost and triple superphosphate (COM + TSP) and a control (P0) without additional P fertilizer. TSP was applied annually at rates of about $21.8 \mathrm{~kg} \mathrm{P} \mathrm{ha}^{-1}$ until 2013 and at a rate of $30 \mathrm{~kg} \mathrm{P} \mathrm{ha}^{-1}$ from 2014. Manure and compost were applied every third year since 1998 (latest application before test period in 2016) at a rate of about $30 \mathrm{t} \mathrm{ha}^{-1}$. Controls received no P fertilizer. In 1998, the initial concentration of double lactate soluble $\mathrm{P}\left(\mathrm{P}_{\mathrm{dl}}\right)$ was $42.2 \mathrm{mg} \mathrm{P} \mathrm{kg}^{-1}$. That indicates a suboptimal $\mathrm{P}$ supply according to the German soil phosphorus classification [14].

At the end of August 2018, after the harvest of winter barley, initial soil samples were taken and nutrient stocks determined (see Table 1). Afterwards, plots were divided into two subplots. One was sown with the catch crop French serradella (Ornithopus sativus, variety "Margherita") while the other half was left as a bare fallow. In spring, serradella was incorporated by ploughing and spring barley (Hordeum vulgare, variety "Planet") was sown all over the plots. Fertilization was performed shortly after the seeding $\left(70 \mathrm{~kg} \mathrm{~N} \mathrm{ha}^{-1}\right)$ and in the early development of BBCH $30\left(150 \mathrm{~kg} \mathrm{~K} \mathrm{ha}^{-1}\right)$.

Table 1. Initial soil $C$ and nutrient element stocks ( $C_{\text {tot }}$ : total carbon; $N_{\text {tot }}$ : total nitrogen; $P_{\text {tot }}$ total phosphorus) of the different fertilization treatments ( $\mathrm{P} 0$ - no additional $\mathrm{P}, \mathrm{TSP}$ - triple superphosphate; COM-compost; COM + TSP-compost + TSP) at the beginning of the experiment at the test site Rostock in 2018; post hoc Tukey HSD $p<0.05$; abc = differences between treatments.

\begin{tabular}{cccc}
\hline Fertilization & $\mathbf{C}_{\text {tot }}\left(\mathbf{g ~ k g}^{-\mathbf{1}}\right)$ & $\mathbf{N}_{\text {tot }}\left(\mathbf{g ~ k g}^{-\mathbf{1}}\right)$ & $\mathbf{P}_{\text {tot }}\left(\mathbf{g ~ k g}^{-\mathbf{1}}\right)$ \\
\hline P0 & $7.7 \pm 0.0 \mathrm{a}$ & $0.9 \pm 0.0 \mathrm{a}$ & $0.5 \pm 0.0 \mathrm{c}$ \\
TSP & $7.9 \pm 0.0 \mathrm{a}$ & $1.0 \pm 0.0 \mathrm{a}$ & $0.5 \pm 0.0 \mathrm{bc}$ \\
COM & $9.9 \pm 0.0 \mathrm{~b}$ & $1.1 \pm 0.0 \mathrm{a}$ & $0.5 \pm 0.0 \mathrm{ab}$ \\
COM + TSP & $10.3 \pm 0.0 \mathrm{~b}$ & $1.0 \pm 0.0 \mathrm{a}$ & $0.6 \pm 0.0 \mathrm{a}$ \\
\hline
\end{tabular}

Soil and biomass samples were taken at an early development stage of spring barley (BBCH 33) in May 2019 and shortly before harvesting in July 2019 (BBCH 69). Three soil samples were taken with a corer ( $3 \mathrm{~cm}$ diameter) from the topsoil ( 0 to $10 \mathrm{~cm}$ soil depth) of each subplot. The samples were stored at $4{ }^{\circ} \mathrm{C}$ for microbial analyses. Subsamples were air-dried, sieved to $<2 \mathrm{~mm}$ and milled for chemical analyses. Additionally, five plant samples were collected at the sampling dates. Shoot and root biomass was separated. Shoot biomass was weighted, dried at $60^{\circ} \mathrm{C}$ and milled (Retsch $\mathrm{GmbH}$, Haan, Germany) for elemental analyses. Root samples were cleaned and stored in $\mathrm{H}_{2} \mathrm{O}$ at $4{ }^{\circ} \mathrm{C}$.

\subsection{Analyses of Carbon, Nitrogen and Phosphorus in Plant and Soil}

Total concentrations of carbon and nitrogen in plant and soil (Tables S1 and S2) were determined by a CNS-Analyzer (Vario EL, Fa. Foss Heraeus, Hanau, Germany) using airdried and milled plant and soil material (DIN ISO 10694: 1996-08, DIN ISO 13787: 1998-11). Double lactate-extractable $\mathrm{P}\left(\mathrm{P}_{\mathrm{dl}}\right)$ was determined by extracting $\mathrm{P}$ from $0.6 \mathrm{~g}$ soil with $30 \mathrm{~mL}$ lactate solution $[26,27]$. The phosphate concentrations in the extract were measured with inductively coupled plasma optical emission spectroscopy (ICP-OES, Optima 8300, Perkin Elmer, Waltham, MA, USA) at a wavelength of $214.914 \mathrm{~nm}$. $\mathrm{P}_{\mathrm{DL}}$ has been considered to represent the plant-available $\mathrm{P}$ in soils $[28,29]$.

The $\mathrm{P}$ concentration in plant material was determined by digesting $0.1 \mathrm{~g}$ biomass with $5 \mathrm{~mL} \mathrm{HNO}_{3}$ and $3 \mathrm{~mL} \mathrm{H}_{2} \mathrm{O}_{2}$ in a microwave (Mars Xpress, CEM, Kamp-Lintfort, Germany) followed by diluting with $\mathrm{H}_{2} \mathrm{O}$ dest. to a volume of $25 \mathrm{~mL}$ (DIN 38406-E22). Concentrations of $\mathrm{P}$ were measured with ICP-OES at a wavelength of $214.914 \mathrm{~nm}$.

\subsection{Analyses of Mycorrhizal Colonization and Soil Enzyme Activities}

For the determination of the mycorrhizal colonization, fine roots were rinsed with distilled water and cut into 10-millimeter sections. The segments were cleared with 10\% 
$\mathrm{KOH}$ at room temperature for $24 \mathrm{~h}$ and acidified for $15 \mathrm{~min}$ in $1 \% \mathrm{HCl}$, and the fungal root colonizations were stained with $0.05 \%$ chlorazol black E [30]. Quantification of the arbuscular mycorrhiza formation was performed using the intersection method [31].

The potential activities of the acid and alkaline phosphomonoesterase (ACP and ALP), phosphodiesterase (PDE) and B-glucosidase (GLA) enzymes were determined. Activities were measured in $\mu \mathrm{g}$ p-nitrophenol by released phenol from a previously administered substrate solution in $1 \mathrm{~g}$ field moisture soil within $1 \mathrm{~h}\left(\mu \mathrm{g} \mathrm{p}\right.$-nitrophenol $\left.\mathrm{g}^{-1} \mathrm{~h}^{-1}\right)$ [32-35]. Based on a suggestion by Nannipieri et al., the method was minimally modified by not adding toluene for this short incubation time [36].

\subsection{Statistical Analyses}

Statistical analysis of the data was performed with $\mathrm{R}$ (Version 1.2.1335) and the associated R packages hmisc (https:/ / cran.r-project.org/web/packages/Hmisc/index.html; version 4.4-2, accessed on 2 August 2021) and agricolae (https:/ / cran.r-project.org/web/ packages/agricolae/index.html; version 1.3-2; accessed on 2 August 2021) and with PAST3 (PAleontological STatistics Version 3). Differences between the treatments were considered as significant at $p<0.05$.

\section{Results}

\subsection{Plant-Available P Content in the Soil}

The plant-available $\mathrm{P}$ content in the soil was strongly influenced by the applied fertilizers and did not follow a seasonal pattern (see Figure 2, Table 2). The highest amounts of plant-available P in soil were measured on plots where the combined COM + TSP fertilization was applied with up to $6.5 \mathrm{mg} \mathrm{P} 100 \mathrm{~g}^{-1}$ soil. Values in the TSP and COM treatments were lower and reached only $4-5 \mathrm{mg}$ P $100 \mathrm{~g}^{-1}$ soil. As expected, the control plots without fertilization had the lowest values. Interestingly, the catch crop showed an effect only at the later samplings. Here, the P-unfertilized plots with serradella pre-cropped showed higher values compared to the bare fallow subplots.

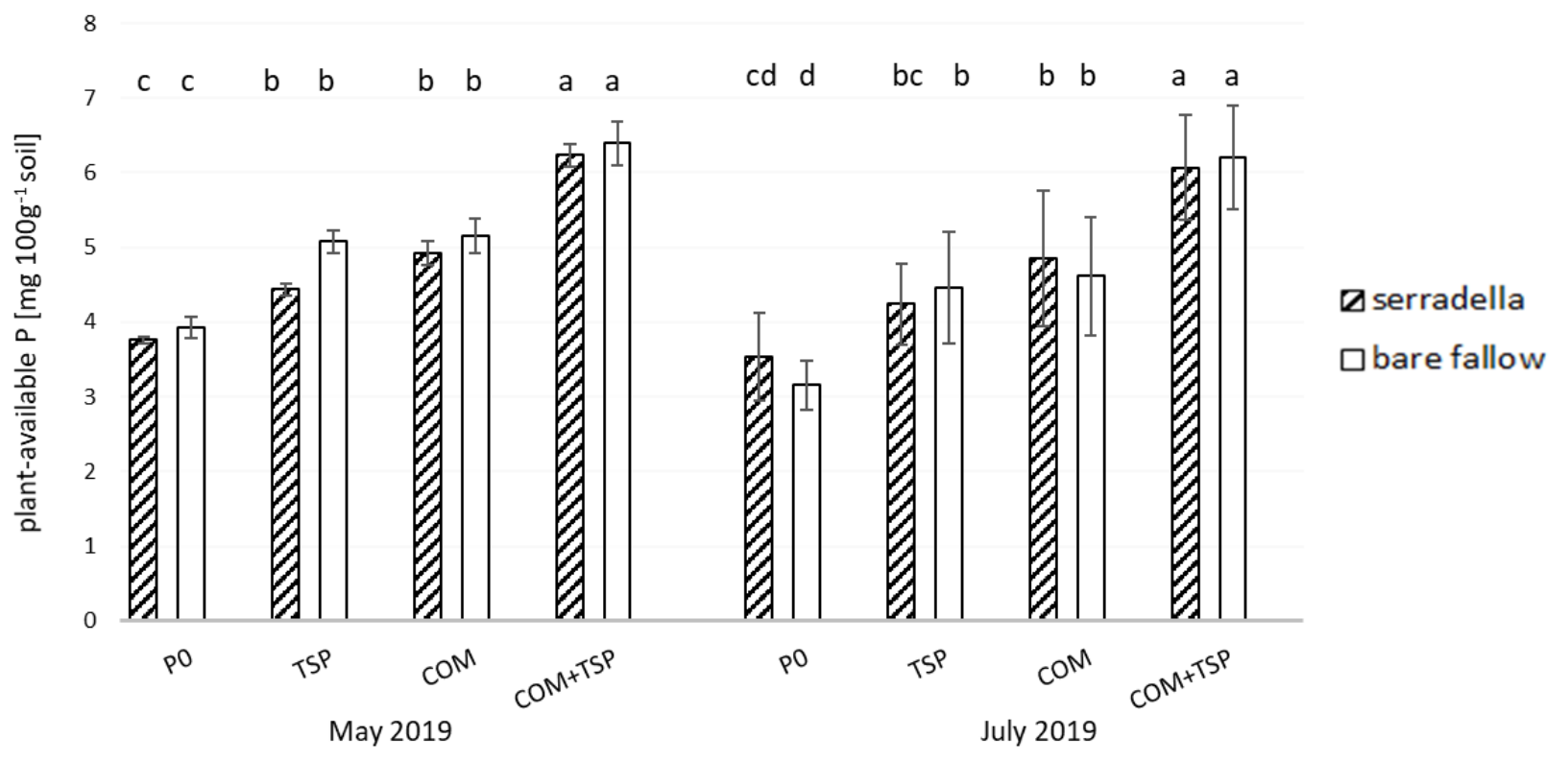

Figure 2. Content of plant-available $\mathrm{P}\left(\mathrm{mg} 100 \mathrm{~g}^{-1}\right.$ soil) in the rhizosphere of spring barley affected by different fertilizer treatments $(\mathrm{P} 0$ —no additional $\mathrm{P}$; TSP—triple superphosphate; $\mathrm{COM} —$ compost; $\mathrm{COM}+\mathrm{TSP}$-compost + triple superphosphate) and pretreatment (with/without catch crop) in May and July 2019 at the test site in Rostock; post hoc test Tukey HSD $p<0.05$; bars with small letters indicate significant differences between fertilization and treatment in the sampling. 
Table 2. Results of two-way analysis of variance (ANOVA) on the effect of treatment with/without catch crop, fertilization and their interaction (treatment $\times$ fertilization) on potential acid and alkaline phosphomonoesterases activities (ACP, ALP), phosphodiesterases activities (PDE), $\beta$-glucosidases activities (GLA), plant-available phosphorus (P-DL), arbuscular mycorrhizal fungi (AMF) colonization, $\mathrm{P}$ in plant biomass (P-plant) and C:N ratio in biomass (C/N plant) of spring barley from May 2019 and July 2019 on the test site of Rostock. Bold numbers indicate significant differences $(p<0.05)$.

\begin{tabular}{|c|c|c|c|c|c|}
\hline Sampling & Parameter & & Treatment & Fertilization & Interaction \\
\hline \multirow{16}{*}{ May 2019} & \multirow{2}{*}{$\mathrm{ACP}$} & $p$ & 0.828 & 0.507 & 0.931 \\
\hline & & $\mathrm{F}$ & 0.048 & 0.854 & 0.209 \\
\hline & \multirow{2}{*}{ ALP } & $p$ & 0.965 & 0.025 & 0.971 \\
\hline & & $\mathrm{F}$ & 0.002 & 3.445 & 0.127 \\
\hline & \multirow{2}{*}{ PDE } & $p$ & 0.229 & 0.062 & 0.899 \\
\hline & & $\mathrm{F}$ & 1.534 & 2.630 & 0.263 \\
\hline & \multirow{2}{*}{ GLA } & $p$ & 0.002 & 0.097 & 0.906 \\
\hline & & $\mathrm{F}$ & 12.660 & 2.243 & 0.251 \\
\hline & \multirow{2}{*}{ P-DL } & $p$ & 0.980 & $<0.001$ & 0.998 \\
\hline & & $\mathrm{F}$ & $<0.001$ & 9.540 & 0.032 \\
\hline & \multirow{2}{*}{$\mathrm{AMF}$} & $p$ & $<0.001$ & 0.679 & 0.287 \\
\hline & & $\mathrm{F}$ & 28.930 & 0.583 & 1.339 \\
\hline & \multirow{2}{*}{ P-plant } & $p$ & 0.549 & 0.002 & 0.973 \\
\hline & & $\mathrm{F}$ & 0.370 & 5.894 & 0.123 \\
\hline & \multirow{2}{*}{$\mathrm{C} / \mathrm{N}$ plant } & $p$ & 0,268 & 0.416 & 0.497 \\
\hline & & $\mathrm{F}$ & 1.293 & 1.026 & 0.871 \\
\hline \multirow{10}{*}{ July 2019} & \multirow{2}{*}{$\mathrm{ACP}$} & $p$ & 0.894 & 0.546 & 0.631 \\
\hline & & $\mathrm{F}$ & 0.018 & 0.786 & 0.653 \\
\hline & \multirow{2}{*}{ ALP } & $p$ & 0.053 & 0.160 & 0.434 \\
\hline & & $\mathrm{F}$ & 4.172 & 1.823 & 0.989 \\
\hline & \multirow{2}{*}{ PDE } & $p$ & 0.240 & 0.630 & 0.831 \\
\hline & & $\mathrm{F}$ & 1.460 & 0.654 & 0.364 \\
\hline & \multirow{2}{*}{ GLA } & $p$ & 0.157 & 0.527 & 0.622 \\
\hline & & $\mathrm{F}$ & 2.150 & 0.818 & 0.667 \\
\hline & \multirow{2}{*}{ P-DL } & $p$ & 0.815 & 0.002 & 0.857 \\
\hline & & $\mathrm{F}$ & 0.036 & 6.161 & 0.327 \\
\hline
\end{tabular}

\subsection{Potential Soil Enzyme Activities and Mycorrhiza Formation}

As expected, all potential enzymatic activities showed a clear seasonal dynamic with higher activities at the earlier sampling in May (see Figure 3). Only for the ß-glucosidase this effect was not visible. The activity of GLA in the rhizosphere of spring barley on the bare fallow subplots surpassed the activity in comparison to the catch-crop-pretreated subplots in May and in July (Table 2).

In May, for the alkaline phosphomonoesterase and phosphodiesterases, clear effects of the fertilizer and increased values were visible. In general, the supply of organic amendments (COM, COM + TSP) resulted in higher potential activities in comparison to the treatments with inorganic fertilizer (TSP) or without additional P fertilizer (P0), except for acid phosphomonoesterase activities. There were no significant differences between P0 and TSP or between COM and COM + TSP. Fertilizer-specific differences were mainly stronger in May 2019 than in July 2019 with the exception of ACP.

The arbuscular mycorrhizal (AM) colonization on the fine roots of spring barley in May 2019 ranged from 34 to 49\% (see Figure 4). 


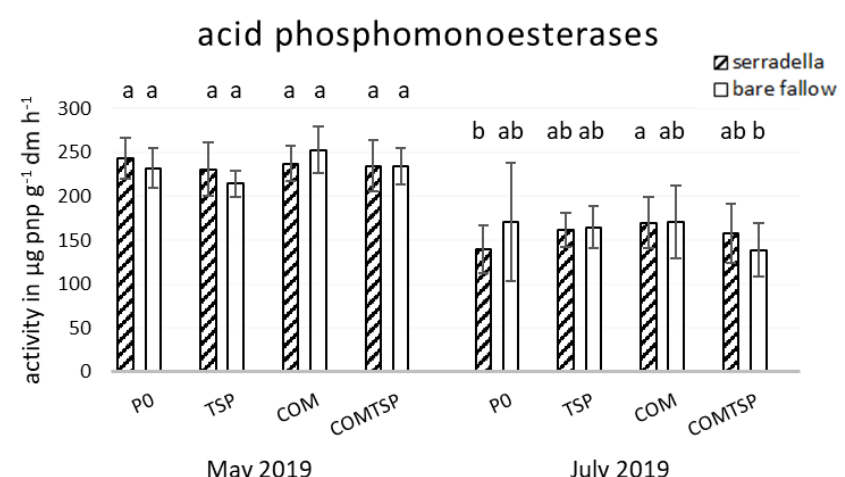

(a)

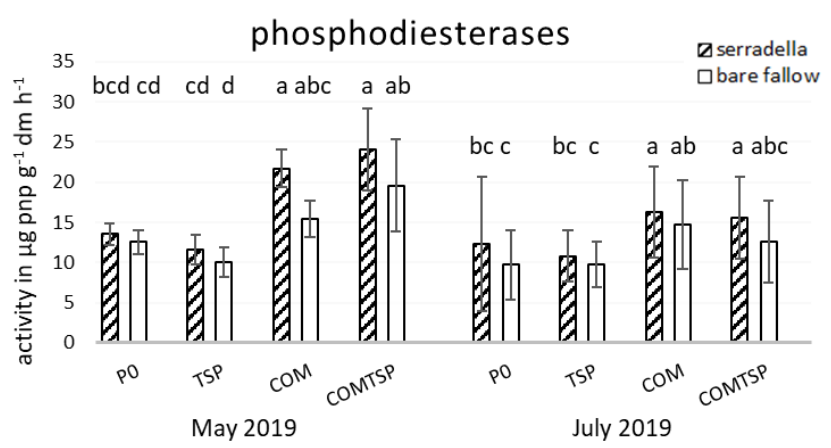

(c)

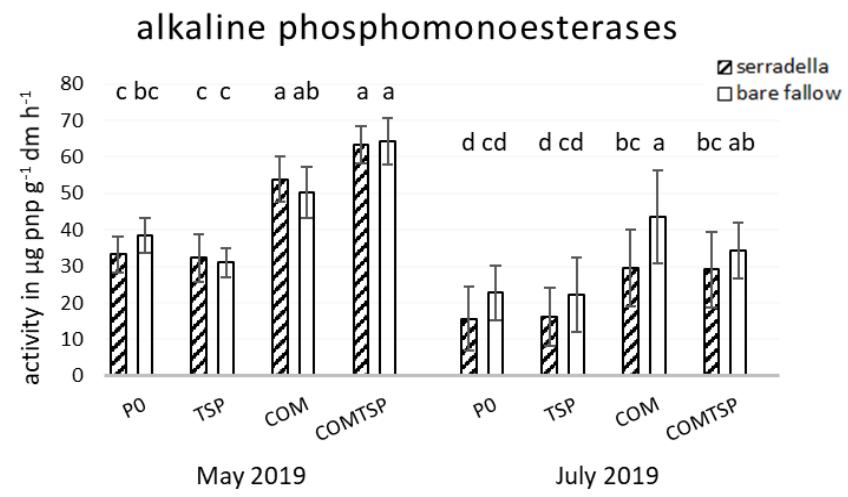

(b)

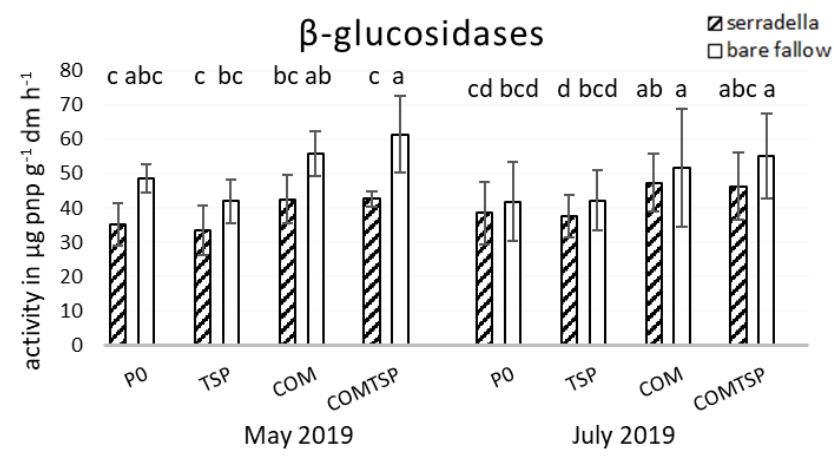

(d)

Figure 3. Potential soil enzyme activities of (a) acid phosphomonoesterases (ACP), (b) alkaline phosphomonoesterases (ALP), (c) phosphodiesterases (PDE) and (d) $\beta$-glucosidases (GLA) in May and July 2019 as affected by fertilization ( $\mathrm{P}$-no additional $\mathrm{P}$; TSP—triple superphosphate; COM-compost; COM + TSP-compost + triple superphosphate) and pretreatment (with/without catch crop) at the field experiment in Rostock; post hoc test Kruskal-Wallis $p<0.05$; abcd $=$ differences between treatments and fertilization within a sampling date.

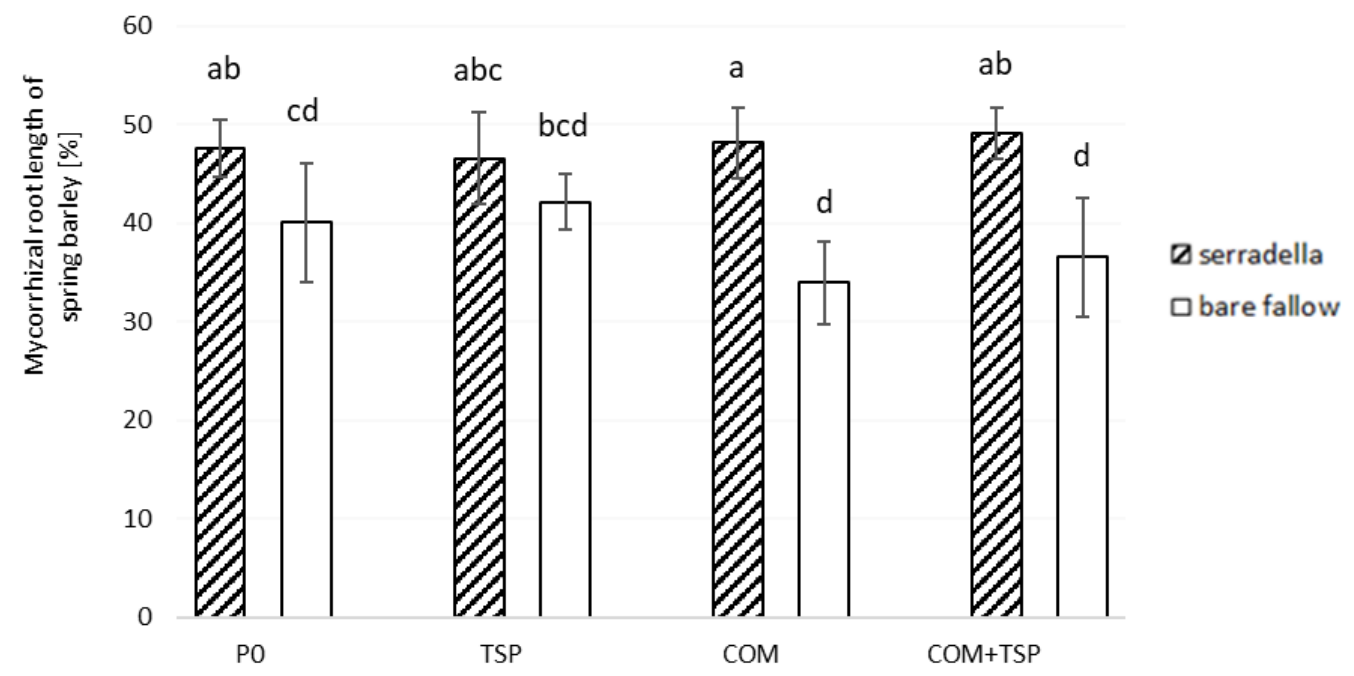

Figure 4. Arbuscular mycorrhizal colonization of barley (BBCH 33) affected by pretreatment (with/without catch crop) and fertilization in May 2019 on the test site of Rostock; post hoc test Kruskal-Wallis $p<0.05$; bars with different small letters indicate significant differences between treatment and fertilization.

On the plots with previous catch crops, the fine roots of spring barley had significantly higher mycorrhizal colonization in comparison to the bare fallow plots (Table 2). 
The fertilization did not affect the AMF abundance. All fertilization treatments within the pretreatments (catch crop or bare fallow) had almost the same level of mycorrhizal colonization. The serradella-pretreated organic fertilized (COM) plots resulted in a $14 \%$ higher formation of arbuscular mycorrhizal root length of spring barley compared to bare fallow plots. The lowest impact on the abundance of mycorrhiza within a fertilization treatment was found with the mineral fertilizer (TSP) with a difference of $4.5 \%$.

Figure 5 shows the negative correlation of mycorrhizal colonization and potential $\beta$-glucosidases activities. Increasing soil enzyme activities led to a decreasing abundance of mycorrhiza formation.

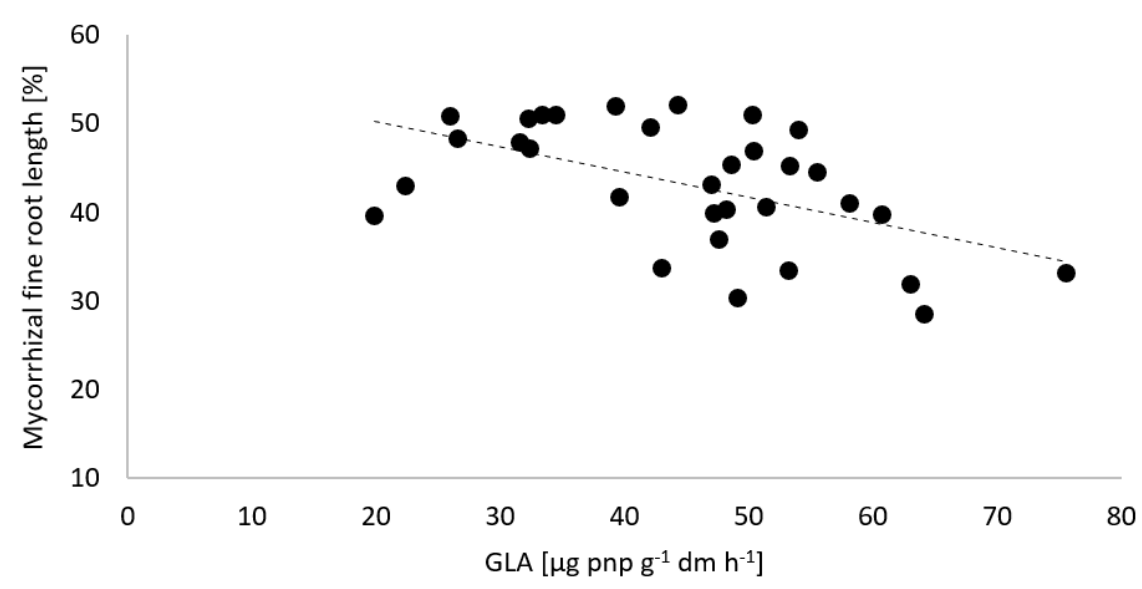

Figure 5. Correlation of the arbuscular mycorrhizal fine root length of spring barley and the potential $\beta$-glucosidases (GLA) activity in the rhizosphere of spring barley in May 2019 at the test site of Rostock.

\subsection{Grain Yield and P Content in the Shoot of Spring Barley}

The grain yield of spring barley ranged from 30 to $40 \mathrm{dt} \mathrm{ha}^{-1}$ (see Figure 6). The lowest yield was revealed with P-unfertilized treatment (P0). Pre-cropping of serradella did not affect the corn yield of spring barley significantly, whereas any $\mathrm{P}$ application tended to generate a yield increase.

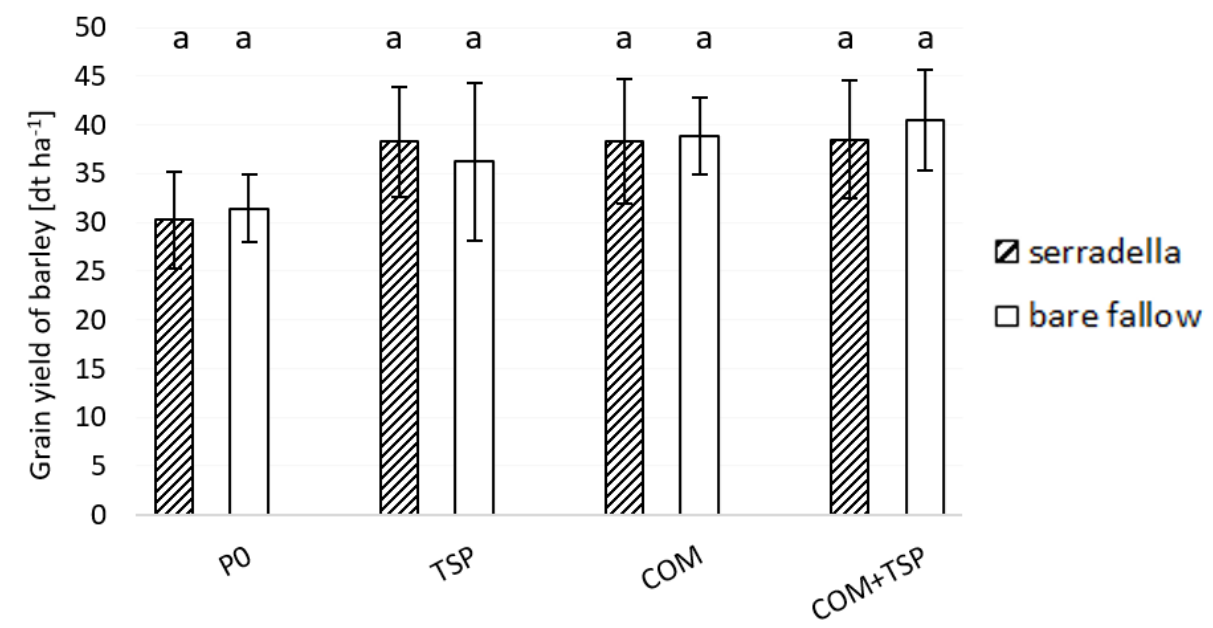

Figure 6. Grain yield of spring barley $\left(\mathrm{dt} \mathrm{ha}^{-1}\right)$ in August 2019 affected by fertilization (P0-no additional $\mathrm{P}$; $\mathrm{TSP}$ — triple superphosphate; $\mathrm{COM}$-compost; $\mathrm{COM}+\mathrm{TSP}$-compost + triple superphosphate) and with/without serradella as previous crop; post hoc Tukey HSD $p<0.05 ; \mathrm{a}=$ no differences between treatments and fertilization. 
The shoot $\mathrm{P}$ content differed significantly within the growing season between May and June (see Figure 7). It was significantly lower with P0 $\left(4.2 \mathrm{mg} \mathrm{g}^{-1}\right)$ than with fertilizer treatments (5-6.5 $\mathrm{mg} \mathrm{P} \mathrm{g}^{-1}$ ) in May 2019. The overall effect of the catch crop was revealed at $\mathrm{BBCH} 33$ (see Table 2). The values obtained from the plants shortly before harvest were in the range of $3 \mathrm{mg} \mathrm{P} \mathrm{g}^{-1}$. Here, a significant effect of the fertilizer and the previous crop was revealed only with TSP fertilization. The P content in shoots grown after bare fallow was higher than that after serradella growth. The shoot P content with P0 did not differ from that with the fertilizer treatments.

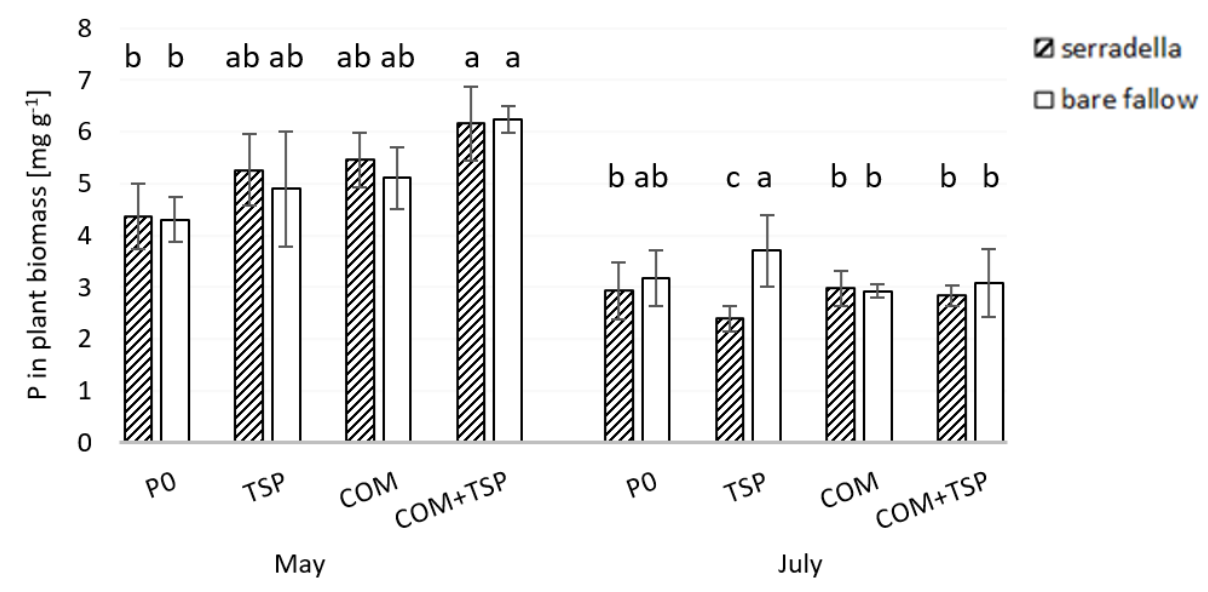

Figure 7. Phosphorus in aboveground biomass $\left(\mathrm{mg} \mathrm{g}^{-1}\right)$ of spring barley (BBCH 33 and 69) affected by different fertilization treatments ( $\mathrm{P} 0$ - no additional $\mathrm{P}$; TSP — triple superphosphate; COMcompost; COM + TSP-compost + triple superphosphate) and with/without serradella as pre-crop in May and July 2019 at the test site of Rostock; post hoc Tukey HSD $p<0.05$; abc = differences between treatments and fertilization within the sampling date.

\section{Discussion}

The analyses revealed that pre-cropping of serradella can promote mycorrhiza formation of subsequent grown barley compared to previous bare fallow in all treatments of fertilization (Figure 4). This confirms that the crop rotation is a significant factor in the control of mycorrhizal abundance [24,37,38]. In the present study, the mycorrhizal colonization of barley ranged from 34 to $49 \%$ of the fine root length (see Figure 4 ). This is in the lower range of mycorrhizal colonization of barley observed in a study of Castillo et al. in Andosols in southern Chile (from 30 up to $80 \%$ of the fine root length) [39]. Although it is known that the mycorrhizal colonization of cereals, such as barley, can vary significantly $[40,41]$, increased colonization is, in general, assumed to be an indicator of increased mycorrhizal dependency of the host plant [42]. Consequently, the increased mycorrhizal dependency of barley after serradella cropping confirms our hypothesis that catch crops promote the growth of AM fungi, even in response to a non-host plant (serradella). This is in line with results of Poveda et al. [43], who found mycorrhiza formation even on non-host plants (Brassicaceae) under favorable rhizosphere conditions. Furthermore, a meta-analysis of seven studies with 60 observations on different catch crop types indicated the potential of catch crops for mycorrhiza formation [44]. Our results specified this for the first time for the cropping of barley after serradella.

Barley is known for its rather low mycorrhiza dependency and responds similarly to non-host crops on mycorrhizal colonization by elevated levels of endogenous jasmonic acid as a host defense against infections $[40,45]$. For this reason, the combination of a previous non-host with a following host with low mycorrhiza dependency might provide favored competitive fungal partners in increased root colonization (see Figure 4). Previous results on catch cropping before the mycorrhizal host plant maize revealed a wide range of crop-specific impacts on the mycorrhiza formation of maize [24]. This underlines that defined combinations of catch crops and main crops have to be tested individually. Under barley, the increased mycorrhizal colonization was significantly correlated with 
decreased potential B-glucosidase activity in the soil (see Figure 7). This correlation might be explained by increased translocation of assimilates as a $C$ source to soil microorganisms by mycorrhizal plants and a consequently decreased need for saprotrophic $C$ supply by the enzymatic hydrolysis of polysaccharides [46]. The ß-glucosidase activity links the C cycling with P mobilization [47] and is affected by organic fertilization, similar to phosphatase activities (see Figure 3).

Both organic fertilization and cover crops are known to control soil enzyme activities in $\mathrm{C}$ and $\mathrm{P}$ cycling [38,48-50]. The increased soil enzyme activities in treatments with organic amendments (COM, COM + TSP) in the present study agree with the results in response to compost application by Peine et al. (2019) and those in response to municipal wastewater sludge by Dindar et al. (2015) [38,49]. The impact of organic amendments is assumed to be based on the addition of substrates for the enzymes and on the general promotion of microbial activity in the soil by an improved nutrient supply [51].

In contrast to the fertilization, previous growth of the catch crop serradella had no considerable effects on the activities on hydrolytic soil enzymes (phosphatases and ß-glucosidase) under barley in the present study (see Figure 5). However, in the metaanalysis of Hallama et al. (2019), up to $20 \%$ increased phosphatase activities after catch cropping were reported [44]. Especially legumes, such our test crop serradella, had the largest effects on soil phosphatase activities. We assume that the dominating effects of fertilization masked the impact of the catch crop in the present study [38].

The plant-available P content in the present non-P-fertilized control (P0: 3.1-3.9 mg $\mathrm{P} 100 \mathrm{~g}^{-1}$ soil) revealed $\mathrm{P}$ deficiency according to the German fertilizer recommendations, while in the treatments with a mix of compost and mineral fertilizer (COM + TSP), an optimal plant availability of P was measured [29]. In consequence, this fertilized treatment had up to $31 \%$ higher $\mathrm{P}$ contents than the control in the early growth of barley. The P supply in early growth is known to be particularly important for the later yield [52]. The dimension of the significant effect of fertilization under P-deficient conditions agrees with the results for other different crops in the studies of Cadot et al. (2018) and Gao et al. (2016) [53,54]. Similar tendencies were observed for maize cropping in the study of Peine et al. (2019) at the same test site [38].

In contrast to the fertilization, pre-growth of serradella had no lasting effect on the $\mathrm{P}$ availability in soil under subsequent grown spring barley, although the general potential of serradella to increase the plant availability of $\mathrm{P}$ in soil is known [14]. Additionally, the P content in the aboveground biomass of spring barley was not affected by the pre-growth of serradella. In contrast to our results, Talgre et al. (2012) reported increased P contents in barley grains by $29-71 \%$ due to previous legume catch crops (red clover, lucerne hybrid, birds-foot) along with increased plant-available P contents in two field experiments [15].

Focusing on the effects of serradella on all measured plant traits (C:N ratio, P in plant biomass, mycorrhizal colonization) of spring barley still revealed a differentiation but also a slight overlapping from the treatment grown on the bare fallow (see Figure 8).

Among the plant traits studied, the mycorrhiza formation of the subsequent crop was especially sensitive to the pre-cropping of serradella. Therefore, we conclude that the mycorrhiza formation of the subsequent crop suitably indicates the catch crop effects on the microbial $\mathrm{P}$ transfer in soil. Since this effect was particularly pronounced in plots with organic amendments, it is concluded that organic amendments cannot substitute the growing of catch crops in the rotation regarding mycorrhiza promotion. Since these conclusions are derived from the investigation of one catch crop at one field site, we propose testing a wider range of catch crops to evaluate the crop-specific soil ecology and also the economic value of mycorrhiza promotion by catch crops to allow generalized management recommendations. 


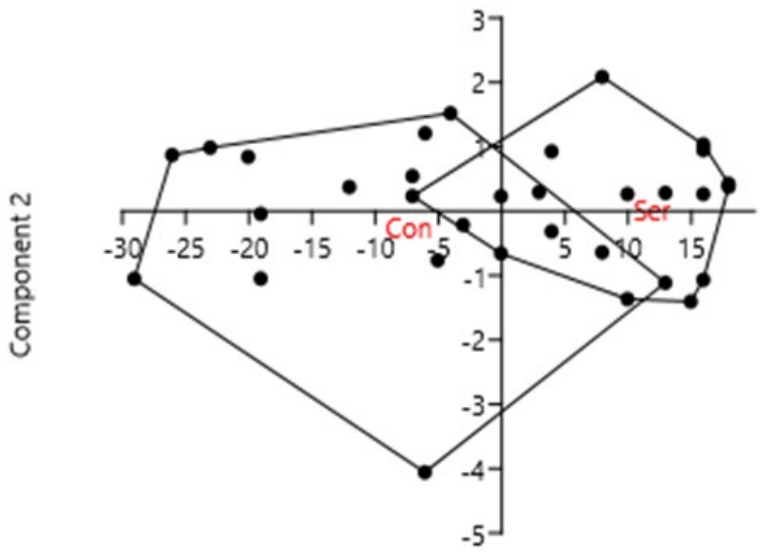

Component 1

Figure 8. Principal component analysis (PCA) of plant properties (C:N ratio, $\mathrm{P}$ in plant biomass and mycorrhizal colonization) as affected by pretreatment (with catch crop-Ser; without catch crop-Con) in the field experiment in Rostock.

Supplementary Materials: The following are available online at https: / www.mdpi.com/article/ 10.3390 /agronomy11122437/s1, Table S1: Plant nutrients of spring barley $\left(\mathrm{C}_{\text {tot }}\right.$ : total carbon, $\mathrm{N}_{\text {tot }}$ : total nitrogen) affected by fertilization ( $\mathrm{P} 0$ - no additional $\mathrm{P}$; $\mathrm{TSP}$ - triple superphosphate; $\mathrm{COM}$ compost; COM + TSP-compost + TSP) and treatment with/without serradella in May and July 2019 on the test site Rostock. Mean values \pm standard deviation; post hoc test Tukey HSD $p<0.05$; $\mathrm{abc}=$ differences between fertilization and treatment within the sampling date. Table S2: Soil nutrient stocks $\left(\mathrm{C}_{\text {tot }}\right.$ : total carbon, $\mathrm{N}_{\text {tot }}$ : total nitrogen, $\mathrm{P}_{\text {tot }}$ : total phosphorus) affected by fertilization (P0—no additional P, TSP — triple superphosphate; COM-compost; COM + TSP — compost + TSP) and treatment with/without serradella in May and July 2019 on the test site Rostock. Mean values \pm standard deviation; post hoc test Kruskal-Wallis $p<0.05$; abc $=$ differences between fertilization and treatment within the sampling date.

Author Contributions: Conceptualization, C.B., S.S. and M.S.; methodology, C.B.; software, N.V.; validation, A.Z., T.Z. and B.E.-L.; formal analysis, N.V. and A.Z.; investigation, N.V., A.Z. and A.C.; resources, T.Z. and B.E.-L.; data curation, N.V. and T.Z.; writing-original draft preparation, N.V.; writing-review and editing, C.B.; visualization, N.V.; supervision, P.L.; project administration, A.Z.; funding acquisition, P.L., B.E.-L., M.S. and C.B. All authors have read and agreed to the published version of the manuscript.

Funding: These investigations were carried out in the BonaRes project InnoSoilPhos (No. 031A558) which was funded by German Federal Ministry of Education and Research (BMBF).

Data Availability Statement: All data were presented in the present article.

Acknowledgments: The authors acknowledge the valuable technical assistance of B. Balz and E. Heilmann (Soil Science, University of Rostock) as well as J. Bremer, Friederike Bischof and J. Bertram. The authors gratefully acknowledge the German Federal Ministry of Education and Research (BMBF) for funding the BonaRes project InnoSoilPhos (No. 031A558). This research was performed within the scope of the Leibniz ScienceCampus Phosphorus Research Rostock.

Conflicts of Interest: The authors declare no conflict of interest.

\section{References}

1. Mengel, K.; Kirkby, E.A. Principles of Plant Nutrition: Phosphorus, 5th ed.; Kosegarten, H., Appel, T., Eds.; Kluwer Academic Publishers: Amsterdam, The Netherlands, 2001; pp. 453-479.

2. Mengel, K. Agronomic measures for better utilization of soil and fertilizer phosphates. Eur. J. Agron. 1997, 7, 277-289. [CrossRef]

3. Mar, S.S.; Okazaki, M. Investigation of Cd contents in several phosphate rocks used for the production of fertilizer. Microchem. J. 2012, 104, 17-21. [CrossRef]

4. Kratz, S.; Schick, J.; Schnug, E. Trace elements in rock phosphates and P containing mineral and organo-mineral fertilizers sold in Germany. Sci. Total Environ. 2016, 542, 1013-1019. [CrossRef] [PubMed] 
5. Redecker, D.; Kodner, R.; Graham, L.E. Glomalean Fungi from the Ordovician. Sci. Total Environ. 2000, 289, 1920-1921. [CrossRef] [PubMed]

6. Helgason, T.; Fitter, A.H. Natural selection and the evolutionary ecology of the arbuscular mycorrhizal fungi (Phylum Glomeromycota). J. Exp. Bot. 2009, 60, 2465-2480. [CrossRef]

7. Hou, L.; Zhang, X.; Feng, G.; Zheng, L.; Zhang, Y.; Cao, N. Arbuscular mycorrhizal enhancement of phosphorus uptake and yields of maize under high planting density in the black soil region of China. Sci. Rep. 2021, 11, 1-11. [CrossRef]

8. Smith, S.E.; Read, D. Mycorrhizal Symbiosis, 3rd ed.; Academic Press: San Diego, CA, USA, 2008; pp. 17-144.

9. Miransari, M. Contribution of arbuscular mycorrhizal symbiosis to plant growth under different types of soil stress. Plant. Biol. 2010, 12, 563-569. [CrossRef]

10. Smith, S.; Facelli, E.; Pope, S.; Andrew Smith, F. Plant performance in stressful environments; interpreting new and established knowledge of the roles of arbuscular mycorrhizas. Plant Soil 2010, 326, 3-20. [CrossRef]

11. Smith, S.E.; Smith, F.A. Roles of arbuscular mycorrhizas in plant nutrition and growth: New paradigms from cellular to ecosystems scales. Annu. Rev. Plant Biol. 2011, 63, 227-250. [CrossRef]

12. Łukowiak, R.; Grzebisz, W.; Sassenrathc, G.F. New insights into phosphorus management in agriculture-A crop rotation approach. Sci. Total Environ. 2016, 542, 1062-1077. [CrossRef]

13. Bakhshandeh, S.; Corneo, P.E.; Mariotte, P.; Kertesz, M.A. Effect of crop rotation on mycorrhizal colonization and wheat yield under different fertilizer treatments. Agric. Ecosyst. Environ. 2017, 247, 130-136. [CrossRef]

14. Eichler-Löbermann, B.; Köhne, S.; Kowalski, B.; Schnug, E. Effect of catch cropping on phosphorus bioavailability in comparison to organic and inorganic fertilization. J. Plant Nutr. 2008, 31, 659-676. [CrossRef]

15. Talgre, L.; Lauringson, E.; Roostalu, H.; Astover, A.; Makke, A. Green manure as nutrient source for succeeding crops. Plant Soil Environ. 2012, 58, 275-281. [CrossRef]

16. Meissner, R.; Rupp, H.; Seeger, J.; Schonert, P. Influence of mineral fertilizers and different soils types on nutrient leaching: Results of lysimeter studies in East Germany. Land Degrad. Rehabil. 1995, 6, 163-170. [CrossRef]

17. Orzech, K. Spring Barley in Pure Sowing and Witch Catch Crops in Crop Rotations. Ph.D. Thesis, University of Warmia and Mazury, Olsztyn, Poland, 2013.

18. Liu, J.; Bergkvist, G.; Ulen, B. Biomass production and phosphorus retention by catch crops on clayey soils in southern and central Sweden. Field Crop. Res. 2015, 171, 130-137. [CrossRef]

19. Kling, C.; Doering, T. Manifold green manures-Part V: French Serradella and subterranean clover. Org. Grow. $2014,26,32-33$.

20. Stepkowski, T.; Zak, M.; Moulin, L.; Kroliczak, J.; Golinksa, B.; Narozna, D.; Safronova, V.I.; Madrzak, C.J. Bradyrhizobium canariense and Bradyrhizobium japonicum are the two dominant rhizobium species in root nodules of lupin and Serradella plants growing in Europe. Syst. Appl. Microbiol. 2011, 34, 368-375. [CrossRef]

21. Vargas, L.K.; Volpiano, C.G.; Lisboa, B.B.; Giongo, A.; Beneduzi, A.; Passaglia, L.M.P. Microbes for Legume Improvement, 2nd ed.; Zaidi, A., Khan, M.S., Musarrat, J., Eds.; Springer International Publishing AG: Cham, Switzerland, 2017; pp. 153-174. [CrossRef]

22. Kidd, D.R.; Ryan, M.H.; Hailing, R.E.; Lambers, H.; Sandral, G.A.; Yang, Z.; Culvenor, R.A.; Cawthray, G.; Stefanski, A.; Simpson, R.J. Rhizosphere carboxylates and morphological root traits in pasture legumes and grasses. Plant Soil 2016, 402, 77-89. [CrossRef]

23. Hajiboland, R.; Sadeghzadeh, N.; Moradtalab, N.; Aliasgharzad, N.; Schweikert, K.; Poschenrieder, C. The arbuscular mycorrhizal mycelium from barley differentially influences various defense parameters in the non-host sugar beet under co-cultivation. Mycorrhiza 2020, 30, 647-661. [CrossRef]

24. Njeru, E.M.; Avio, L.; Sbrana, C.; Turrini, A.; Bocci, G.; Barberi, P.; Giovanetti, M. First evidence for a major cover crop effect on arbuscular mycorrhizal fungi and organic maize growth. Agron. Sustain. Dev. 2013, 34, 841-849. [CrossRef]

25. IUSS Working Group WRB. World Reference Base for Soil Resources 2014, Update 2015 International Soil Classification System for Naming Soils and Creating Legends for Soil Maps; World Soil Resources Reports No. 106; FAO: Rome, Italy, 2015.

26. Riehm, H. Arbeitsvorschrift zur Bestimmung der Phosphorsäure und des Kaliums nach Lactatverfahren. Z Pflanzenernähr Düng Bodenkd 1948, 40, 152-156.

27. VDLUFA. Methode A 6.2.1.2-Bestimmung von Phosphor und Kalium im Doppellactat (DL)-Auszug, in Verband Deutscher Landwirtschaftlicher Untersuchungs- und Forschungsanstalten (ed.): VDLUFA-Methodenbuch, Band I, Die Untersuchung von Boden, 4th ed.; VDLUFA-Verlag: Darmstadt, Germany, 2002.

28. Schachtschabel, P.P.; Beyme, B. Löslichkeit des anorganischen Bodenphosphors und Phosphatdüngung. J. Plant Nutr. Soil Sci. 1980, 143, 306-316. [CrossRef]

29. Kerschberger, M.; Hege, L.; Jungk, A. Phosphordüngung nach Bodenuntersuchung und Pflanzenbedarf; VDLUFA Standpunkt, VDLUFA Verlag: Darmstadt, Germany, 1997.

30. Brundrett, M.C.; Piché, Y.; Peterson, R.L. A new method for observing the morphology of vesicular-arbuscular mycorrhizae. Can. J. Bot. 1983, 62, 2128-2134. [CrossRef]

31. McGonigle, T.P.; Miller, M.H.; Evans, D.G.; Fairchild, G.L.; Swan, J.A. A new method which gives an objective measure of colonization of roots by vesicular-arbuscular mycorrhizal fungi. New Phytol. 1990, 115, 495-501. [CrossRef]

32. Tabatabai, M.A.; Bremner, J.M. Use of p-nitrophenyl phosphate for assay of soil phosphatase activity. Soil Biol. Biochem. 1969, 1, 301-307. [CrossRef]

33. Browman, M.G.; Tabatabai, M.A. Phosphodiesterase activity of soils. Soil Sci. Soc. Am. J. 1978, 42, 284-290. [CrossRef] 
34. Tabatabai, M.A. Soil Enzymes. In Methods of Soil Analysis. Part 2; Page, A.L., Miller, R.H., Keeney, D.R., Eds.; ASA: Madison, WI, USA, 1982; pp. 903-948.

35. Eivazi, F.; Tabatabai, M.A. Phosphatases in soils. Soil Biol. Biochem. 1977, 9, 167-172. [CrossRef]

36. Nannipieri, P.; Johnson, R.L.; Paul, E.A. Criteria for measurement of microbial growth and activity in soil. Soil Biol. Biochem. 1978, 10, 223-229. [CrossRef]

37. Falkowski, P.G.; Fenchel, T.; Delong, E.F. The microbial engines that drive earth's biogeochemical cycles. Science 2008, 320, 1034-1039. [CrossRef] [PubMed]

38. Peine, M.; Vitow, N.; Grafe, M.; Baum, C.; Zicker, T.; Eichler-Löbermann, B.; Schulz, S.; Schloter, M.; Leinweber, P. Effect of triple superphosphate and biowaste compost on mycorrhizal colonization and enzymatic P mobilization under maize in a long-termin field experiment. J. Plant Nutr. Soil Sci. 2019, 182, 167-174. [CrossRef]

39. Castillo, C.G.; Puccio, F.; Morales, D.; Borie, F.; Sieverding, E. Early arbuscular mycorrhiza colonization of wheat, barley and oats in Andosols of southern Chile. J. Soil. Sci. Plant Nutr. 2012, 12, 511-524. [CrossRef]

40. Hetrick, B.A.D.; Wilson, G.W.T.; Todd, T.C. Mycorrhizal response in wheat cultivars: Relationship to phosphorus. Can. J. Bot. 1996, 74, 19-25. [CrossRef]

41. Grace, E.J.; Cotsaftis, O.; Tester, M.; Smith, F.A.; Smith, S.E. Arbuscular mycorrhizal inhibition of growth in barley cannot be attributed to extent of colonization, fungal phosphorus uptake or effects on expression of plant phosphate transporter genes. New Phytol. 2009, 181, 938-949. [CrossRef]

42. Graham, J.T.; Eissenstat, D.M.; Drouillard, D.L. On the relationship between a plant's mycorrhizal dependency and rate of vesicular mycorrhizal colonization. Funct. Ecol. 1991, 5, 773-779. [CrossRef]

43. Poveda, J.; Hermosa, R.; Monte, E.; Nicolás, C. Trichoderma harzianum favours the access of arbuscular mycorrhizal fungi to non-host Brassicaceae roots and increases plant productivity. Sci. Rep. 2019, 9, 1-11. [CrossRef] [PubMed]

44. Hallama, M.; Pekrun, C.; Lambers, H.; Kandeler, E. Hidden miners-the roles of cover crops and soil microorganisms in phosphorus cycling through agroecosystems. Plant Soil 2019, 434, 7-45. [CrossRef]

45. Hause, B.; Maier, W.; Miersch, O.; Kramell, R.; Strack, D. Induction of jasmonate biosynthesis in arbuscular mycorrhizal barley roots. Plant Physiol. 2002, 130, 1213-1220. [CrossRef]

46. Kaiser, C.; Kilburn, M.R.; Clode, P.L.; Fuchslueger, L.; Koranda, M.; Cliff, J.B.; Solaiman, Z.M.; Murphy, D.V. Exploring the transfer of recent plant photosynthates to soil microbes: Mycorrhizal pathway vs direct root exudation. New Phytol. 2015, 205, 1537-1551. [CrossRef] [PubMed]

47. Loeppmann, S.; Breidenbach, A.; Spielvogel, S.; Dippold, M.A.; Blagodatskaya, E. Organic Nutrients Induced Coupled Cand P-Cycling Enzyme Activities During Microbial Growth in Forest Soils. Front. For. Glob. Change 2020, 3-100. [CrossRef]

48. Trinchera, A.; Ciaccia, C.; Testani, E.; Baratella, V.; Campanelli, G.; Leteo, F.; Canali, S. Mycorrhiza-mediated interference between cover crop and weed in organic winter cereal agroecosystems: The mycorrhizal colonization intensity indicator. Ecol. Evol. 2019, 9, 1-12. [CrossRef]

49. Dindar, E.; Şağban, F.O.; Başkaya, H.S. Evaluation of soil enzyme activities as soil quality indicators in sludge-amended soils. J. Environ. Biol. 2015, 36, 919-926. [PubMed]

50. Gianfreda, L.; Ruggiero, P. Enzyme activities in soil. In Nucleic Acids and Proteins in Soil; Nannipieri, P., Smalla, K., Eds.; Springer: Berlin/Heidelberg, Germany, 2006; Volume 8, pp. 257-311. [CrossRef]

51. Nannipieri, P.; Giagnoni, L.; Landi, L.; Renella, G. Role of phosphatase enzymes in soil. In Phosphorus in Action: Biological Processes in Soil Phosphorus Cycling; Bunemann, E., Oberson, A., Frossard, E., Eds.; Springer: Berlin/Heidelberg, Germany, 2011; Volume 26, pp. 251-244.

52. Bindraban, P.S.; Dimkpa, C.O.; Pandey, R. Exploring phosphorus fertilizers and fertilzation strategies for improved human and environmental health. Biol. Fertil. Soils 2020, 56, 299-317. [CrossRef]

53. Cadot, S.; Bélanger, G.; Ziadi, N.; Morel, C.; Sinaj, S. Critical plant and soil phosphorus for wheat, maize, and rapeseed after 44 years of P fertilizer. Nutr. Cycl. Agroecosyst. 2018, 112, 417-433. [CrossRef]

54. Gao, Y.; Cooper, D.J.; Ma, X. Phosphorus addition have no impact on plant biomass or soil nitrogen in an alpine meadow on the Qinghai-Tibetan Plateau, China. Appl. Soil Ecol. 2016, 106, 18-23. [CrossRef] 